\title{
Antibiofilm and Antiviral Potential of Leaf Extracts from Moringa oleifera and Rosemary (Rosmarinus officinalis Lam.)
}

\author{
Mohamed A. Nasr-Eldin\#, Ahmed G. Abdelhamid and Dina M. Baraka \\ Botany Department, Faculty of Science, Benha University, Benha, Egypt.
}

\begin{abstract}
$\mathbf{T}$ HE RISE of antimicrobial drug resistance due to biofilms and improper use of conventional drugs poses a major concern in medicinal fields. This work evaluates the antibiofilm and antiviral potential of leaf extracts from Moringa oleifera and Rosemarinus officinalis (Rosemary). Three different concentrations (20, 40 and $60 \mathrm{mg} / \mathrm{ml})$ of $M$. oleifera leaves aqueous extract were investigated for their inhibitory potential on initial cell attachment of Staphylococcus aureus cells to the microtiter plate well surface. The concentration $(60 \mathrm{mg} / \mathrm{ml})$ resulted in $28.57 \%$ inhibition of biofilm formation as compared to $4.96 \%$ inhibition in the presence of $20 \mathrm{mg} / \mathrm{ml}$ of the same extract. In contrast, $S$. aureus was more susceptible to rosemary methanol extract with $41.30 \%$ inhibition using $10 \mathrm{mg} / \mathrm{ml}$ of the extract. Moreover, at non cytotoxic concentration, the inhibitory effect of $M$. oleifera and rosemary extracts have been separately evaluated against herpes simplex virus type 1 (HSV-1) and type 2 (HSV-2). The results indicated that $200 \mu \mathrm{g} / \mathrm{ml}$ and $100 \mu \mathrm{g} / \mathrm{ml}$ for $M$. oleifera and rosemary extracts, respectively, were considerably safe for Vero cells as cell survival was above $90 \%$. In addition, the percentage of inhibition was 43.2 and $21.4 \%$ for HSV-1and HSV-2, respectively by M. oleifera extract while rosemary caused $18.9 \%$ inhibition for HSV-1 and no inhibitory activity against HSV-2 was observed.Thus, results uncovered inhibitory potential of $M$. oleifera and rosemary leaf extracts on initial attachment of $S$. aureus to surfaces towards biofilm formation. In addition, $M$. oleifera extract was more effective than rosemary as antiviral agent against herpes simplex viruses.
\end{abstract}

Keywords: Antibiofilm, Antiviral, Plant extract, Staphylococcus aureus, HSV

\section{Introduction}

Biofilms are structural components including a community of bacterial cells within a selfproduced polymeric matrix and adhering to an inert or living surface (Costerton et al., 1999). The key features of biofilms are the elevated resistance to antimicrobials than the sessile cells making their elimination a big challenge (Simões et al., 2011). Being important in human diseases, the number of biofilm-associated infections increases dramatically (Davies, 2003). Biofilm infections of Staphylococcus aureus, especially the medical device-associated infections are difficult to be eradicated using most of the currently available treatments (Lynch \& Robertson, 2008).

The increase of biofilm resistance to traditional treatments such as antibiotics or chemical preservatives and their associated adverse side effects triggers a great interest to search for safer alternatives (Ahmad et al., 2014; Onsare \& Arora,
2015). Plant-based antimicrobials gain much publicity because of their safety and long history of use. One of these plants is Moringa oleifera (Stohs \& Hartman, 2015). The anti-inflammatory, antibacterial, and antifungal activities of $M$. oleifera were well characterized (Koheil et al., 2011; Oluduro, 2012 and Peixoto et al., 2011). In addition, Rosmarinus officinalis (Rosemary) has been recognized as an important member of medically important plants (Petiwala et al., 2014). The antioxidant and antimicrobial properties of rosemary extracts has been well-documented (Bubonja-Sonje et al., 2011).

The extracts derived from seeds, leaves, roots and fruits of medicinal plants exhibited antiviral activities against RNA and DNA viruses (Kanekiyo et al., 2008 and Todorov et al., 2015). A large number of bioactive plant constituents, such as phenolics and flavonoids found in leaves have been reported to be active anti-herpetic agents (Khan et al., 2005). 
Herpes simplex viruses are large enveloped double stranded DNA viruses with icosahedral symmetry, categorized into Herpes simplex virus type 1 (HSV-1/ oral herpes) and herpes simplex virus type 2 (HSV-2/ genital herpes) of the family of Herpesviridae. This family of viruses has been known to establish lifelong latency causing recurrent episodes of the disease. Both viruses cause infections that are mostly asymptomatic but can cause painful blisters or ulcers at the site of infection of the nervous system around the lips, in the eyes, in the mucous membrane of the oral cavity and also in the genitals (Kenneth \& Ray, 2004). Transmission occurs by contact with secretions from an infected person with either overt infection or asymptomatic excretion of virus. Acyclovir and penciclovir are now drugs for treatment of HSV infection but viral resistance against acyclovir has become an arising problem in the therapy of herpes simplex viruses' diseases especially for the treatment of immune-compromised patients (Villarreal, 2003). Due to resistance of pathogens to chemical drugs, the search for biological active extracts based traditionally used plants is still relevant. Investigations for antiviral activity of some plant leaves extracts represent an important step in finding an alternative viral disease treatment. Crude extracts of plant materials are a promising source of systemic broad spectrum antiviral that may cause less damage to host cells than do pharmaceuticals (Barakat et al., 2010 and Kim et al., 2016). Leaves' extracts of $M$. oleifera are mostly used as food items, folk traditional medicine of Africa and South Asia and for a variety of medicinal purposes (Jung, 2014). The inhibitory properties of $M$. oleifera have been stated against much viral diseases (Murakami et al., 1998 and Nworu et al., 2013). Rosemary is an aromatic evergreen herb shrub that is widely distributed in the Mediterranean region. Polyphenols derived from aromatic plants and spices have been used as natural antiviral agents (Cushnie \& Lamb, 2005; García et al., 2003 and Khan et al., 2005), specifically, the flavonoids including galangin, quercetin, procyanidin, pelargonidin and procyanidin C-1 (Amoros et al., 1992; Meyer et al., 1997 and Shahat et al., 2002). The antiviral effect of these substances is greatest when used before virus adsorption (Lyu et al., 2005 and Shahat et al., 2002). Based on the promising safety, antimicrobial and antiviral characteristics of $M$. oleifera and rosemary against pathogens, our work aimed here to explore their antibiofilm and antiviral potential against the biofilm forming $S$. aureus and herpes simplex viruses.

\section{Materials and Methods}

\section{Plant extracts preparation}

The experiments used leaves of $M$. oleifera and rosemary which were collected from botanical gardens of Faculty of Agriculture, Ain-Shams University, Egypt. For preparation of aqueous extracts; 20, 40 and $60 \mathrm{mg}$ of M.oleifera dry leaves were homogenized into a fine powder in a mortar and pestle device very gently and dissolved in 1 $\mathrm{ml}$ of sterile distilled water. For rosemary, dry powdered leaves $(10,20$ and $40 \mathrm{mg} / \mathrm{ml})$ were used for the biofilm experiment. Dry powdered plant leaves were extracted in soxhlet apparatus using petroleum ether (2:2.5 volumes) for $8 \mathrm{~h}$. After extraction, the solvent was evaporated using rotary vacuum evaporator to give a concentrated extract at $60^{\circ} \mathrm{C}$ in a water bath, then dried aseptically and subjected to gas chromatography-mass spectroscopic (GC-MS) analysis.

\section{Inoculum preparation}

Initial active bacterial inoculum for the biofilm experiment was prepared as described earlier (Arora \& Kaur, 1999). A loopful of well-isolated colonies of S.aureus (obtained from Department of Agricultural Microbiology, Faculty of Agriculture, Ain Shams University, Egypt) was transferred into $5 \mathrm{ml}$ of nutrient broth (Oxoid, UK) and incubated for $16 \mathrm{~h}$ at $37^{\circ} \mathrm{C}$ to obtain the cells at exponential phase.

\section{Evaluation of antibiofilm potential}

Attachment of free cells onto a surfaceto form sessile cells is the first stage towards biofilm development. Disruption of the initial attachment process of the cells is the starting point of finding promising antibiofilm agents. The antibiofilm formation activity of $M$. oleifera and rosemary leaf extracts was assessed as previously described (Jadhav et al., 2013). Two sets labeled test agents (M. oleifera and rosemary) along with their respective experimental control (broth medium) were prepared in microtitre plate. A series of inhibitory concentrations of test antibiofilm agents as previously described (Elhariry et al., 2014 and Oluduro, 2012) were prepared. In each case, 100 $\mu l$ of the test antibiofilm agent prepared in different inhibitory concentrations (M. oleifera extract; 20, 40 and $60 \mathrm{mg} / \mathrm{ml}$; rosemary extract $10,20,40 \mathrm{mg} /$ $\mathrm{ml}$ ) was added in triplicate to the corresponding wells of sterile flat-bottomed 96-well microtitre plate (Sigma Aldrich, USA) except the negative controls (untreated cells). Equal volumes of the bacterial cultures were added into wells in all the 
sets (except the experimental control in which same volume of broth medium was added instead) so as to have a final volumeof $200 \mu \mathrm{l}$ per well. The microtitre plates were sealed and incubated for 16 $h$ at $37^{\circ} \mathrm{C}$. The inhibition of initial cell attachment in the presence of the test agents corresponds to the biofilm biomass as compared to negative control was established using crystal violet assay. The results have been expressed as percentage of inhibition.

The estimation of biofilm biomass was carried out after the treatment periods in preceding experiments. Quantification of the biomass was carried out by crystal violet (CV) assay (Djordjevic et al., 2002) with slight modifications. The evaluation is based on the fact that the dye penetrates and stains cell membranes of attached cells thereby providing information of their density. The amount of stain absorbed is directly proportional to the amount of biofilm on surfaces. After incubation of treated test organisms, the culture medium from each well was discarded and washed two times with sterile distilled water to wash away any loosely adhered cells. The air-dried wells were further dried in the oven at $60^{\circ} \mathrm{C}$ for 40 min and then stained with $150 \mu 1$ of $0.1 \%$ crystal violet before incubating at room temperature for 20 min. After incubation, the wells were again washed two times with sterile distilled water to remove unabsorbed stain. For estimating biofilm density, the absorbance was determined at $595 \mathrm{~nm}$ using an automated microplate reader (Sun Rise-TECAN. Inc. ${ }^{\circledR}$ USA). The mean absorbance $\left(\mathrm{OD}_{595 \mathrm{~mm}}\right)$ of test organisms was determined and the percentage inhibition was calculated using the following formula (Equation 1):

Percentage inhibition $=100-\left(\left(\mathrm{OD}_{595 \mathrm{~nm}}\right.\right.$ test for positive control well $/ \mathrm{OD}_{595 \mathrm{~nm}}$ negative control well) $\mathrm{x}$ 100)

\section{Herpes simplex virus}

Herpes simplex type 1 and type 2 virus stocks were prepared by infecting cell lines in plastic flasks at $37^{\circ} \mathrm{C}$. The cells were checked by microscopy for cytopathic effects (CPE). At 75\% CPE, the medium was decanted and stored at $-70^{\circ} \mathrm{C}$. HSV-1 and HSV-2were propagated and quantified at 50\% tissue culture infective dose $\left(\mathrm{TCID}_{50}\right)$ by end point dilution (Flint et al., 2015).

\section{Cell line}

African green monkey kidney cell lines (Vero cells) were obtained from European Collection of Cell Cultures (ECACC). The cells were grown in Dulbecco's modified Eagle's medium (DMEM) (Life Technologies, Inc.) supplemented with 10\% heat-inactivated FBS, $2 \mathrm{mM}$ glutamine, and 1\% gentamycinat $37^{\circ} \mathrm{C}$ with $5 \% \mathrm{CO}_{2}$.

\section{Cytotoxicity assay}

Cytotoxicity of each extract was monitored on Vero cells. Vero cells were propagated in DMEM supplemented with $10 \%$ heat-inactivated fetal calf serum, $1 \%$ L-glutamine, HEPES buffer and $50 \mu \mathrm{g} /$ $\mathrm{ml}$ gentamycin. The cells were seeded onto 96-well microtitre plates (Falcon, NJ, USA) at $10^{4} \mathrm{cell} / \mathrm{s} / \mathrm{ml}$. Fresh maintenance medium containing different concentrations of the $M$. oleifera and rosemary leaves extracts were added after $24 \mathrm{~h}$ of seeding. Control cells were incubated without test material. The plates were incubated in a humidified incubator with $5 \% \mathrm{CO}_{2}$ at $37^{\circ} \mathrm{C}$ for $48 \mathrm{~h}$. Each concentration of test extracts was loaded into six wells. Detectable alterations in morphology of the cells were inspected daily. By MTT assay, the optical density was measured at $490 \mathrm{~nm}$ using ELISA reader (Vmax Molecular Devices) to determine the number of viable cells, and the viability percentage was calculated as $\left[1-\left(\mathrm{OD} / \mathrm{OD}_{\mathrm{c}}\right)\right] \mathrm{x} 100 \%$ where $\mathrm{OD}_{\mathrm{t}}$ is the mean optical density of wells separately treated with the $M$. oleifera and rosemary leaves extracts and $\mathrm{OD}_{\mathrm{c}}$ is the mean optical density of untreated cells (Mosmann, 1983).

\section{Evaluation of antiviral activity}

The antiviral activity of the tested aqueous extract derived from $M$. oleifera and methanol extract from rosemary leaves was separately evaluated by MTT method (Mosmann, 1983). Briefly; monolayers of Vero cells were seeded into 96-well culture plate at $10^{5}$ cells $/ \mathrm{ml}$ with a volume of $100 \mu \mathrm{l} /$ well. After $24 \mathrm{~h}$ of incubation at $37^{\circ} \mathrm{C}$ in a $\mathrm{CO}_{2}$ incubator, $100 \mu \mathrm{l}$ of $100 \mathrm{TCID}_{50}$ of the herpes simplex type 1 or type 2 virus was added, and the infected cells were incubated for another $2 \mathrm{~h}$. The medium is removed after incubation, and $125 \mu \mathrm{l}$ of experimental leaves extract is added to the first row in triplicate wells, all other wells having $100 \mu \mathrm{l}$ of DMEM with $2 \%$ fetal calf serum. The test material in the first row of wells is then diluted serially 1:5 throughout the remaining wells by transferring $25 \mu \mathrm{l}$. After further incubation at $37^{\circ} \mathrm{C}$ with $5 \% \mathrm{CO}_{2}$ for $48 \mathrm{~h}$, MTT was added. The culture was incubated for $4 \mathrm{~h}$ to allow the production of formazan, and then $100 \mu \mathrm{l}$ of acidified isopropanol $(0.04 \mathrm{~N} \mathrm{HCl}$ in isopropanol) 
was added to each well to dissolve any formazan produced. The $M$. oleifera and rosemary leaves extracts were evaluated using a minimum of 6 replicates. The amount of formazan produced is directly proportional to the number of surviving cells. A positive growth control, 6 wells/plate, contained non-infected Vero cells grown in the presence of $0.2 \%$ DMSO. A viral death control, 6 wells/plate, contained viral infected cells. The plate was measured at $490 \mathrm{~nm}$. Data manipulated by computer outfitted with the Softmax Pro ${ }^{\circledR}$ software and linked to the plate reader. The $\mathrm{A}_{490}$ values, corrected for the cytotoxicity exerted by test extracts (as determined in non-infected cultures), were used to calculate the percent cell viability (Fernandez-Pol et al., 2001).

Viral inhibition rate was estimated using the following formula:

Viral inhibition percentage $=\left[\left(\mathrm{OD}_{\mathrm{tv}}-\mathrm{OD}_{\mathrm{cv}}\right) /\right.$ $\left.\left(\mathrm{OD}_{\mathrm{cd}}-\mathrm{OD}_{\mathrm{cv}}\right)\right] \times 100 \%$

where $\mathrm{OD}_{\mathrm{tv}}, \mathrm{OD}_{\mathrm{cv}}$ and $\mathrm{OD}_{\mathrm{cd}}$ are the absorbance of test extracts with virus infected cells, the absorbance of the virus control and the absorbance of the cell control, respectively.

\section{Analysis by gas chromatography-mass spectrometry ( $G C$ - $M S)$}

The chemical composition of the aqueous extract of $M$. oleifera and methanol extracts of $R$. officinalis were determined using GC-MS to identify the probable bioactive antibiofilm and antiviral constituents. The GC-MS analysis of the crude extracts were performed using Perkin Elmer system (GC clarus 600, USA) equipped with an AOC-20i autosampler. Gas chromatograph was interfaced to a mass spectrometer (GC-MS) instrument with Elite$5 \mathrm{MS}$ fused silica capillary column $(30.0 \mathrm{~m} \times 0.25$ $\mathrm{mm}$ ID, $250 \mu \mathrm{mdf})$. Detection was operating in electron impact mode with ionization energy of $70 \mathrm{eV}$ with helium (99.99\%) as a carrier gas at flow rate of $1 \mathrm{ml} / \mathrm{min}$. The injection volume of 1 $\mu \mathrm{l}$ of sample was employed (split ratio of 10:1) and the injector temperature was at $240^{\circ} \mathrm{C}$. The oven temperature was $60^{\circ} \mathrm{C}$ with an increase of $10^{\circ} \mathrm{C} / \mathrm{min}$ to $300^{\circ} \mathrm{C} / \mathrm{min}$ for $6 \mathrm{~min}$. The components of the extract were identified by the retention time of the chromatogram peaks and by their mass spectra. The identities of the main components were confirmed by comparison of their retention time with that of reference compounds. The percentage of each compound was calculated as the ratio of the peak area to the total chromatographic area.

\section{Results}

The effect of $M$. oleifera and rosemary extracts on initial cell attachment of $S$. aureus towards biofilm formation was clearly observed. The inhibitory potential against initial cell attachment of rosemary was stronger than $M$. oleifera extract. A decrease in the biomass $\left(\mathrm{OD}_{595 \mathrm{~nm})}\right.$ of $S$. aureus was observed by the gradual increase of $M$. oleifera extract concentrations of which the concentration $(60$ $\mathrm{mg} / \mathrm{ml}$ ) resulted in $28 \%$ inhibition of biofilm formation as compared to $4.96 \%$ and $13.97 \%$ inhibition in the presence of 20 and $40 \mathrm{mg} /$ mlof the same extract, respectively (Table 1). On the other hand, S. aureus was more susceptible to rosemary extract with $41.30 \%$ inhibition using $10 \mathrm{mg} / \mathrm{ml}$ of the crude extract. Increasing the concentration of rosemary extract was surprisingly associated with less inhibitory potential $22.67 \%$ and $23.91 \%$ using 20 and 40 $\mathrm{mg} / \mathrm{ml}$, respectively (Table 1 ). Results showed encouraging inhibitory potential of $M$. oleifera and rosemary leaf extracts being the highest promising at lower concentration against $S$. aureus biofilm formation.

Cytotoxicity assessment of two extracts derived form $M$. oleifera and rosemary leaves showed survival of Vero cells by 92 and $91 \%$ at concentration $200 \mu \mathrm{g} / \mathrm{ml}$ and $100 \mu \mathrm{g} / \mathrm{ml}$, respectively (Table 2). Cell survival of Vero cells was above $50 \%$ using the former concentrations while at higher concentration, cell survival was below 50\% (Data not shown).

The $M$. oleifera and rosemary extracts were investigated for their antiviral activity against herpes simplex viruses. Antiviral assay of $M$. oleifera aqueous extract at concentration of 200 $\mu \mathrm{g} / \mathrm{ml}$ revealed inhibition percentage of $43.2 \%$ and $21.4 \%$ for herpes simplex type 1 and type 2 , respectively. On the other hand, using $100 \mu \mathrm{g} / \mathrm{ml}$ of rosemary extract, inhibitory activity was $18.9 \%$ for herpes simplex type 1 . Moreover, at the same concentration of rosemary extract, no antiviral activity against HSV-2 was observed. Cell survival percentages and antiviral potential mediated by aqueous $M$. oleifera and methanolic extract of rosemary leaves (Table 2). 
TABLE 1. Antibiofilm potential of Moringa oleifera and rosemary leaf extracts against $S$. aureus.

\begin{tabular}{|c|c|c|c|c|c|}
\hline $\begin{array}{l}\text { M. oleifera } \\
\text { extract } \\
(\mathrm{mg} / \mathrm{ml})\end{array}$ & $\begin{array}{l}\text { Mean of } \\
\text { OD }_{595 \mathrm{~nm}}\end{array}$ & $\begin{array}{c}\% \\
\text { Inhibition }\end{array}$ & $\begin{array}{c}\text { Rosemary } \\
\text { extract } \\
(\mathrm{mg} / \mathrm{ml})\end{array}$ & Mean of $O D_{595 \mathrm{~nm}}$ & $\%$ Inhibition \\
\hline 60 & $0.076 \pm 0.007$ & 28.57 & 40 & $0.081 \pm 0.007$ & 23.91 \\
\hline 40 & $0.092 \pm 0.006$ & 13.97 & 20 & $0.083 \pm 0.033$ & 22.67 \\
\hline 20 & $0.102 \pm 0.010$ & 4.96 & 10 & $0.063 \pm 0.003$ & 41.30 \\
\hline 0 (control) & $0.0107 \pm 0.002$ & NA & 0 (Control) & $0.0107 \pm 0.002$ & $\mathrm{NA}^{*}$ \\
\hline
\end{tabular}

*Denotes for not applicable

TABLE 2.Cytotoxicity and antiviral activity of Moringa oleifera and rosemary leaf extracts against Herpes simplex viruses.

\begin{tabular}{|c|c|c|c|c|c|}
\hline \multirow{2}{*}{ Plant name } & \multirow{2}{*}{ Extract } & \multirow{2}{*}{$\begin{array}{c}\text { Concentration } \\
\mu \mathrm{g} / \mathrm{ml}\end{array}$} & \multirow{2}{*}{$\begin{array}{c}\text { \%Vero Cell } \\
\text { survival }\end{array}$} & \multicolumn{2}{|c|}{ \%Inhibition } \\
\hline & & & & HSV-1 & HSV-2 \\
\hline M. oleifera & Aqueous & 200 & 92 & 43.2 & 21.4 \\
\hline Rosemary & Methanol & 100 & 91 & 18.9 & $\mathrm{ND}^{*}$ \\
\hline
\end{tabular}

"ND: Not determined

The GC -MS results for $M$. oleifera and rosemary leaf extracts are presented in Table 3. Only the compounds with relative occurrence $>1 \%$ are reported. The $M$. oleifera leaf extract had 17 compounds accounting for $83.26 \%$ of the total chemical composition of the extract. D.L.Alpha-Tocopherol was the compound found in highest concentration (11.89\%) followed by 2 , 4, 6- cycloheptatrien-1-one,3,5-bis-trimethylsilyl (9.68\%), Trimethyl (4-tert-butyphenoxy) silane (7.51\%), 1-Nonene, 4,6,8- trimethyl (7.0\%),
Oxirane, Hexadecyl (6.70\%) and others as shown in Table 3.

For rosemary, the compound found in the highest concentration was Ferruginol $(4.53 \%)$ as demonstrated in Table 3. Also, Camphor (3.88\%), Cineole $(2.66 \%)$ and Verbenone $(2.50 \%)$ existed in considerable amounts and all in addition to Ferruginol accounted for $15.13 \%$ of the whole chemical composition of the extract (Table 3). 
TABLE 3. Major chemical compounds identified from Moringa oleifera and rosemary leaf extracts and their percentage occurrence $(>1 \%)$.

\begin{tabular}{|c|c|c|}
\hline Name of compound & Molecular formula & Occurrence (\%) \\
\hline \multicolumn{3}{|l|}{ Moringa oleifera } \\
\hline Dibutyl phthalate & $\mathrm{C}_{16} \mathrm{H}_{22} \mathrm{O}_{4}$ & 1.66 \\
\hline 4- Dodecanol & $\mathrm{C}_{12} \mathrm{H}_{26} \mathrm{O}$ & 1.37 \\
\hline $\begin{array}{l}\text { Hexanedioic acid, bis ( } 2- \\
\text { ethylhexyl) }\end{array}$ & $\mathrm{C}_{22} \mathrm{H}_{42} \mathrm{O}_{4}$ & 1.36 \\
\hline Z6, Z9- Pentadecadien-1-ol & $\mathrm{C}_{15} \mathrm{H}_{28} \mathrm{O}$ & 3.20 \\
\hline $\begin{array}{l}\text { Heptane, 2,2,3,3,5,6,,6- } \\
\text { Heptamethyl }\end{array}$ & $\mathrm{C}_{14} \mathrm{H}_{30}$ & 3.86 \\
\hline $\begin{array}{l}\text { 1,2-Benzenedicarboxylic acid, } \\
\text { mono(2-ethylhexyl) ester }\end{array}$ & $\mathrm{C}_{16} \mathrm{H}_{22} \mathrm{O}_{4}$ & 4.34 \\
\hline Hentriacontane & $\mathrm{C}_{31} \mathrm{H}_{64}$ & 3.26 \\
\hline 1-Nonene, 4,6,8- trimethyl & $\mathrm{C}_{12} \mathrm{H}_{24}$ & 7.0 \\
\hline 1-Hexanol, 2-ethyl-2-propyl & $\mathrm{C}_{11} \mathrm{H}_{24} \mathrm{O}$ & 6.04 \\
\hline Squalene & $\mathrm{C}_{30} \mathrm{H}_{50}$ & 5.34 \\
\hline $\begin{array}{l}\text { Trimethyl (4-tert-butyphenoxy) } \\
\text { silane }\end{array}$ & $\mathrm{C}_{13} \mathrm{H}_{22} \mathrm{OSi}$ & 7.51 \\
\hline Tetracontane-1,40-diol & $\mathrm{C}_{40} \mathrm{H}_{82} \mathrm{O}_{2}$ & 2.22 \\
\hline $\begin{array}{l}\text { Tetrapentacontane and } \\
\text { Dotriacontane }\end{array}$ & $\mathrm{C}_{32} \mathrm{H}_{56}$ & 4.16 \\
\hline D.L.Alpha -Tocopherol & $\mathrm{C}_{29} \mathrm{H}_{50} \mathrm{O}_{2}$ & 11.89 \\
\hline Oxirane, Hexadecyl & $\mathrm{C}_{18} \mathrm{H}_{36} \mathrm{O}$ & 6.70 \\
\hline Beta- Amyrin & $\mathrm{C}_{32} \mathrm{H}_{52} \mathrm{O}_{2}$ & 3.64 \\
\hline $\begin{array}{l}\text { 2,4,6- cycloheptatrien-1-one, } 3,5-5 \\
\text { bis-trimethylsilyl }\end{array}$ & $\mathrm{C}_{13} \mathrm{H}_{22} \mathrm{OSi}$ & 9.68 \\
\hline Total & & 83.26 \\
\hline \multicolumn{3}{|l|}{ Rosemary } \\
\hline Cineole & $\mathrm{C}_{10} \mathrm{H}_{18} \mathrm{O}$ & 2.66 \\
\hline Camphor & $\mathrm{C}_{10} \mathrm{H}_{16} \mathrm{O}$ & 3.88 \\
\hline Borneol & $\mathrm{C}_{10} \mathrm{H}_{18} \mathrm{O}$ & 1.56 \\
\hline Verbenone & $\mathrm{C}_{10} \mathrm{H}_{14} \mathrm{O}$ & 2.50 \\
\hline Ferruginol & $\mathrm{C}_{20} \mathrm{H}_{30} \mathrm{O}$ & 4.53 \\
\hline Total & & 15.13 \\
\hline
\end{tabular}




\section{Discussion}

Plants represent a sustainable source of antibiofilm agents with different modes of action and properties (Ahmad et al., 2014). Phytochemical screening of M. oleifera aqueous extract revealed several classes of secondary metabolites such as alkaloids, polyphenols (such as Tocopherol), flavonoids and terpenes (such as Beta-amyrin). Several molecules belonging to these classes were found to be effective against pathogenic microorganisms (Ndhlala et al., 2013 and Viera et al., 2010). The presence of these classes can account for antibiofilm potential of M. oleifera leaf extract (Dzotam et al., 2016). Similarly, the antibiofilm potential of flavonoids extracted from $M$. oleifera seed coat was quite encouraging (Onsare \& Arora, 2015). In addition, flavonoids such as kaempferol present in citrus was proved to exhibit anti-quorum sensing activity by interfering with the acyl-homoserine lactones leading to inhibition of biofilm formation (Vikram et al., 2010). In leaf extract of $M$. oleifera, total flavonoids were estimated to be present in considerable quantities (Vongsak et al., 2013). In this study, the potential of bioactive constituents of $M$. oleifera leaf extract to inhibit initial cell attachment to surfaces is dependent on concentration in a similar way to previous studies (Onsare \& Arora, 2015). This gives credence to our work where increasing concentration of the extract resulted in decrease of cell biomass. However, it is suggested to combine $M$. oleifera extract with other known antibiofilm safe phytocompounds to maximize their potential to render unfavorable conditions for initial attachment of bacterial cells to surfaces. In general, inhibition of such attachment to surfaces may be the starting point to combat formation of biofilm. On the other hand, rosemary extract exhibited promising antibiofilm potential against $S$. aureus. The antimicrobial activities of rosemary against a wide range of microbial pathogens such as S. epidermidis, Escherichia coli and Candida albicans has been reported (Abramovič et al., 2012). In addition, a synergistic antimicrobial activity of rosemary and galangal or lemon iron bark was observed when they are used in combination (Weerakkody et al., 2011). Intriguingly, seven culinary herbs caused at least $50 \%$ reduction of biofilm adhesion of some strains of Listeria monocytogenes but rosemary was one among three that inhibited preformed biofilms (Sandasi et al., 2010). The antibiofilm activity of rosemary extract is thought to be attributed to terpenes (such as Cineole, camphor and borneol) and phenolic constituents (such as Ferruginol) present in the extract (Weerakkody et al., 2011).

On the other hand, this study aimed to investigate the inhibitory effect of two different extracts from medicinal plants against herpes simplex virus using Vero cell line. Aqueous extract from $M$. oleifera showed moderate inhibitory activity against herpes simplex virus type 1 and weak inhibitory effect against herpes simplex virus type 2 at a non-cytotoxic concentration, these results were in accordance to previous studies (Anwar et al., 2007 and Lipipun et al., 2003).

Methanol extract derived from rosemary leaves showed a less inhibitory activity against herpes simplex virus type 1 and no effect on HSV2 where as most HSV-2 strains are highly resistant to acyclovir due to a mutation previously reported in the viral DNA polymerase (Kriesel et al., 2005). The antiviral activity of the two plant extracts used in this work might be related to the presence of phenolic compounds such as ferruginol (Jung, 2014). The phenolic compounds are responsible for the inhibitory effects of lipid peroxidation, antiviral activity against replication of either RNA or DNA viruses, disability of the viral lipidic envelope and interfering with viral compounds required for adsorption and cell entry (García et al., 2003; Minami et al., 2003 and Vadlapudi et al., 2013). Aqueous extract from rosemary possesses antioxidant activity coupled with antiviral action (Mancini et al., 2009). In the same study, the experiments with HSV-1 replication in Vero cells, indicated inhibition of the virus in the range of 85 to $86 \%$ in the presence or absence of both, natural and synthetic antioxidants (Mancini et al., 2009).

Our results demonstrated that aqueous extract of $M$. oleifera showed antiviral activity against HSV-1in Vero cells. These findings suggest that flavonoid compounds such as Beta-amyrin may result in decrease or inhibition of the yield of HSV-1 by an inhibition of viral DNA replication (Nolkemper et al., 2006).

There was no significant difference between acyclovir and M. oleifera extract in the delay of the development of skin lesions (Lipipun et al., 2003). Toxicity of M. oleifera extract was not observed in treated mice. Thus, this plant extract may be possible candidate as anti-HSV-1 agent. 
Our data showed that rosemary extract only had a weak and no inhibitory effect on HSV-1 and HSV2 , respectively so it must be used in a combination with synthetic antioxidant compounds to improve its antiviral activity against herpes simplex viruses. Combination between natural extracts and therapeutic agents has been reported in many investigations. Actium lappa, Calendula officinalis and Geranium robertianum extracts may have different mechanisms of anti-HSV-1 action from acyclovir and thus the combination of acyclovir with herbal extracts might work synergistically (Corina et al., 1999).

The plants used for this study was found to contain phenols, flavonoids and terpenes as a phytochemicals which were demonstrated by GCMS. So there may be a correlation between phenols and all these activities. Finally, the two plant extracts showed antiviral activity but $M$. oleifera extract was more effective than rosemary extract against herpes simplex viruses.

Our work emphasized $M$. oleifera and rosemary could be a rich source for bioactive components that can act as antibiofilm and antiviral agents against pathogens. Therefore, further studies are needed to isolate the bioactive constituents, exploring their mode of action, investigating their synergism when used in combinations and reveal their therapeutic potential in animal models.

\section{References}

Abramovič, H., Terpinc, P., Generalić, I., Skroza, D., Klančnik, A., Katalini, V. and Možina, S.S. (2012) Antioxidant and antimicrobial activity of extracts obtained from rosemary (Rosmarinus officinalis) and vine (Vitis vinifera) leaves. Croat. J. Food Sci. Technol. 4, 1-8.

Ahmad, I., Mabood, F.H., Maheshwari, M. and Zahin, M. (2014) Medicinal plants and phytocompounds: A potential source of novel antibiofilm agents, In: "Antibiofilm Agents". pp. 1-32.

Amoros, M., Simões, C.M., Girre, L., Sauvager, F. and Cormier, M. (1992) Synergistic effect of flavones and flavonols against herpes simplex virus type 1 in cell culture. Comparison with the antiviral activity of propolis. J. Nat. Prod. 55, 1732-1740.

Anwar, F., Latif, S., Ashraf, M. and Gilani, A.H. (2007) Moringa oleifera: A food plant with multiple medicinal uses. Phytother. Res. 21, 17-25.

Arora, D.S. and Kaur, J. (1999) Antimicrobial activity of spices. Int. J. Antimicrob. Agents, 12, 257-262.
Barakat, A.B., Shoman, S. A, Dina, N. and Alfarouk, O.R. (2010) Antiviral activity and mode of action of Dianthus caryophyllus L . and Lupinus termes L. seed extracts against in vitro herpes simplex and hepatitis A viruses infection. J. Microbiol. Antimicrob. 2, 23-29.

Bubonja-Sonje, M., Giacometti, J. and Abram, M. (2011) Antioxidant and antilisterial activity of olive oil, cocoa and rosemary extract polyphenols. Food Chem. 127, 1821-1827.

Corina, P., Dimitris, S., Emanuil, T. and Nora, R. (1999) Treatment with acyclovir combined with a new Romanian product from plants. Oftalmologia, 46, $55-57$.

Costerton, J.W., Stewart, P.S. and Greenberg, E.P. (1999) Bacterial biofilms: A common cause of persistent infections. Science, 284, 1318-22.

Cushnie, T.P.T. and Lamb, A.J. (2005) Antimicrobial activity of flavonoids. Int. J. Antimicrob. Agents. 26, 343-356.

Davies, D. (2003) Understanding biofilm resistance to antibacterial agents. Nat. Rev. Drug Discov. 2, 114-22.

Djordjevic, D., Wiedmann, M. and McLandsborough, L.A. (2002) Microtiter plate assay for assessment of Listeria monocytogenes biofilm formation. Appl. Environ. Microbiol. 68, 2950-2958.

Dzotam, J.K., Touani, F.K. and Kuete, V. (2016) Antibacterial and antibiotic-modifying activities of three food plants (Xanthosoma mafaffa Lam., Moringa oleifera (L.) Schott and Passiflora edulis Sims) against multidrug-resistant (MDR) Gramnegative bacteria. BMC Complement. Altern. Med. 16, 9 .

Elhariry, H., Abuzaid, A.A., Khiralla, G.M. and Gherbawy, Y. (2014) Antibiofilm formation and anti-adhesive (to HEp-2 cells) effects of rosemary water extract against some food-related pathogens. Int. J. Food Sci. Technol. 49, 1132-1141.

Fernandez-Pol, J.A., Klos, D.J. and Hamilton, P.D. (2001) Antiviral, cytotoxic and apoptotic activities of picolinic acid on human immunodeficiency virus-1 and human herpes simplex virus-2 infected cells. Anticancer Res. 21, 3773-3776.

Flint, S.J., Racaniello, V.R., Rall, G. and Skalka, A.M.(Editors) (2015) "Principles of Virology". $4^{\text {th }}$. Washington, DC: ASM, Press.

García, C.C., Talarico, L., Almeida, N., Colombres, S., Duschatzky, C. and Damonte, E.B. (2003) Virucidal activity of essential oils from aromatic plants of San Luis, Argentina. Phyther. Res. 17, 1073-1075. 
Jadhav, S., Shah, R., Bhave, M. and Palombo, E.A. (2013) Inhibitory activity of yarrow essential oil on Listeria planktonic cells and biofilms. Food Control, 29, 125-130. doi:10.1016/j.foodcont. 2012.05.071

Jung, I.L. (2014) Soluble extract from Moringa oleifera leaves with a new anticancer activity. PLoS One, 9. doi:10.1371/journal.pone.0095492

Kanekiyo, K., Hayashi, K., Lee, J.B., Takenaka, H. and Hayashi, T. (2008) Structure and antiviral activity of an acidic polysaccharide from an edible blue-green alga, Nostoc flagelliforme. Yakugaku Zasshi, 128, 725-31.

Kenneth, J.R. and Ray, C.G. (2004) Sherris "Medical Microbiology", Vasa. pp. 727-730.

Khan, M.T.H., Ather, A., Thompson, K.D. and Gambari, R. (2005) Extracts and molecules from medicinal plants against herpes simplex viruses. Antiviral Res. 67, 107-119.

Kim, J.H., Weeratunga, P., Kim, M.S., Nikapitiya, C., Lee, B.H., Uddin, M.B., Kim, T.H., Yoon, J.E., Park, C., Ma, J.Y., Kim, H. and Lee, J.S. (2016) Inhibitory effects of an aqueous extract from Cortex Phellodendri on the growth and replication of broadspectrum of viruses in vitro and in vivo. BMC Complement. Altern. Med. 16, 265.

Koheil, M., Hussain, M., Othman, S. and El haddad, A. (2011) Anti-inflammatory and antioxidant activities of Moringa peregrina Seeds. Free Radicals Antioxidants, 1, 49-61.

Kriesel, J.D., Spruance, S.L., Prichard, M., Parker, J.N. and Kern, E.R. (2005) Recurrent antiviral-resistant genital herpes in an immunocompetent patient. $J$. Infect. Dis. 192, 156-161.

Lipipun, V., Kurokawa, M., Suttisri, R., Taweechotipatr, P., Pramyothin, P., Hattori, M. and Shiraki, K. (2003) Efficacy of Thai medicinal plant extracts against herpes simplex virus type 1 infection in vitro and in vivo. Antiviral Res. 60, 175-180.

Lynch, A.S. and Robertson, G.T. (2008) Bacterial and fungal biofilm infections. Annu. Rev. Med. 59, 415428.

Lyu, S.Y., Rhim, J.Y. and Park, W.B. (2005) Antiherpetic activities of flavonoids against herpes simplex virus type 1 (HSV-1) and type 2 (HSV-2) in vitro. Arch. Pharm. Res. 28, 1293-1301.

Mancini, D.A.P., Torres, R.P., Pinto, J.R. and ManciniFilho, J. (2009) Inhibition of DNA virus: Herpes-1 (HSV-1) in cellular culture replication, through an antioxidant treatment extracted from rosemary spice. Brazilian J. Pharm. Sci. 45, 127-133.
Meyer, J.J.M., Afolayan, A.J., Taylor, M.B. and Erasmus, D. (1997) Antiviral activity of galangin isolated from the aerial parts of Helichrysum aureonitens. $J$. Ethnopharmacol. 56, 165-169.

Minami, M., Kita, M., Nakaya, T., Yamamoto, T., Kuriyama, H. and Imanishi, J. (2003) The inhibitory effect of essential oils on herpes simplex virus type1 replication in vitro. Microbiol. Immunol. 47, 681684.

Mosmann, T. (1983) Rapid colorimetric assay for cellular growth and survival: Application to proliferation and cytotoxicity assays. J. Immunol. Methods, 65, 55-63.

Murakami, A., Kitazono, Y., Jiwajinda, S., Koshimizu, K. and Ohigashi, H. (1998) Niaziminin, a thiocarbamate from the leaves of Moringa oleifera, holds a strict structural requirement for inhibition of tumorpromoter-induced epstein- barr virus activation. Planta Med. 64, 319-323.

Ndhlala, A.R., Amoo, S.O., Ncube, B., Moyo, M., Nair, J.J. and Van Staden, J. (2013) 16 - Antibacterial, antifungal, and antiviral activities of African medicinal plants, in: "Medicinal Plant Research in Africa". pp. 621-659.

Nolkemper, S., Reichling, J., Stintzing, F.C., Carle, R. and Schnitzler, P. (2006) Antiviral effect of aqueous extracts from species of the Lamiaceae family against herpes simplex virus type 1 and type 2 in vitro. Planta Med. 72, 1378-1382.

Nworu, C.S., Okoye, E.L., Ezeifeka, G.O. and Esimone, C.O. (2013) Extracts of Moringa oleifera Lam. showing inhibitory activity against early steps in the infectivity of HIV-1 lentiviral particles in a viral vector-based screening. African J. Biotechnol. 12, 4866-4873.

Oluduro, A.O. (2012) Evaluation of antimicrobial properties and nutritional potentials of Moringa oleifera. Malays. J. Microbiol. 8, 59-67.

Onsare, J.G. and Arora, D.S. (2015) Antibiofilm potential of flavonoids extracted from Moringa oleifera seed coat against Staphylococcus aureus, Pseudomonas aeruginosa and Candida albicans. J. Appl. Microbiol. 118, 313-325.

Peixoto, J.R.O., Silva, G.C., Costa, R.A., de Sousa Fontenelle, J. res L., Vieira, G.H.F., Filho, A.A.F., Vieira, R.H.S. and Dos, F. (2011) In vitro antibacterial effect of aqueous and ethanolic Moringa leaf extracts. Asian Pac. J. Trop. Med. 4, 201-204.

Petiwala, S.M., Berhe, S., Li, G., Puthenveetil, A.G., Rahman, O., Nonn, L. and Johnson, J.J. (2014) Rosemary (Rosmarinus officinalis) extract modulates $\mathrm{CHOP} / \mathrm{GADD} 153$ to promote androgen receptor 
degradation and decreases xenograft tumor growth. PLoS One, 9, e89772.

Sandasi, M., Leonard, C.M. and Viljoen, A.M. (2010) The in vitro antibiofilm activity of selected culinary herbs and medicinal plants against Listeria monocytogenes. Lett. Appl. Microbiol. 50, 30-35.

Shahat, A.A., Cos, P., De Bruyne, T., Apers, S., Hammouda, F.M., Ismail, S.I., Azzam, S., Claeys, M., Goovaerts, E., Pieters, L., Vanden Berghe, D. and Vlietinck, A.J. (2002) Antiviral and antioxidant activity of flavonoids and proanthocyanidins from Crataegus sinaica. Planta Med. 68, 539-541.

Simões, L.C., Lemos, M., Pereira, A.M., Abreu, A.C., Saavedra, M.J. and Simões, M. (2011) Persister cells in a biofilm treated with a biocide. Biofouling, 27, 403-11.

Stohs, S.J. and Hartman, M.J.(2015) Review of the safety and efficacy of Moringa oleifera. Phytother Res 29,796-804.

Todorov, D., Shishkova, K., Dragolova, D., Hinkov, A., Kapchina-Toteva, V. and Shishkov, S. (2015) Antiviral activity of medicinal plant Nepeta nuda. Biotechnol. Biotechnol. Equip. 29, 39-43.

Vadlapudi, A.D., Vadlapatla, R.K. and Mitra, A.K. (2013) Update on emerging antivirals for the management of herpes simplex virus infections: a patenting perspective. Recent Pat. Antiinfect. Drug Discov. 8, 55-67.
Viera, G.H.F., Mourão, J.A., Angelo, A.M., Costa, R.A., Vieira, R.H.S. and Dos, F. (2010) Antibacterial effect (in vitro) of Moringa oleifera and Annona muricata against Gram positive and Gram negative bacteria. Rev. Inst. Med. Trop. Sao Paulo 52, 129-132.

Vikram, A., Jayaprakasha, G.K., Jesudhasan, P.R., Pillai, S.D. and Patil, B.S. (2010) Suppression of bacterial cell-cell signalling, biofilm formation and type III secretion system by citrus flavonoids. J. Appl. Microbiol. 109, 515-527.

Villarreal, E.C., (2003) Current and potential therapies for the treatment of herpes-virus infections. Prog. Drug Res. 60, 263-307.

Vongsak, B., Sithisarn, P., Mangmool, S., Thongpraditchote, S., Wongkrajang, Y. and Gritsanapan, W. (2013) Maximizing total phenolics, total flavonoids contents and antioxidant activity of Moringa oleifera leaf extract by the appropriate extraction method. Ind. Crops Prod. 44, 566-571.

Weerakkody, N.S., Caffin, N., Lambert, L.K., Turner, M.S. and Dykes, G.A. (2011) Synergistic antimicrobial activity of galangal (Alpinia galanga), rosemary (Rosmarinus officinalis) and lemon iron bark (Eucalyptus staigerana) extracts. J. Sci. Food Agric. 91, 461-468.

(Received 5 / 8 /2017;

accepted $27 / 11 / 2017$ ) 


\title{
النشاط المضاد للفشاء الحيوى (البيوفيلم) والمضاد للفيروسات لمستخلصات اوراق المورينجا أوليفيرا و إكليل الجبل الجيل
}

محمد عاطف نصر الدين و احمد غمرى عبدالحميد و دينا محسن بركه

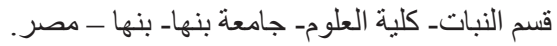

\begin{abstract}
ان ارتفاع مقاومة الميكروبات للعقاقير الطبيه بسبب تكوين الأغشية الحيوية والاستخدام غير السليم لهذه العقاقير

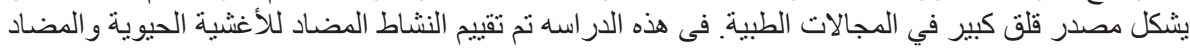

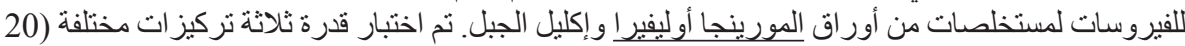

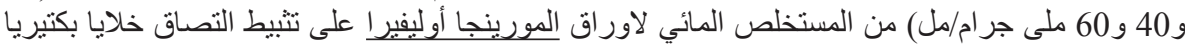

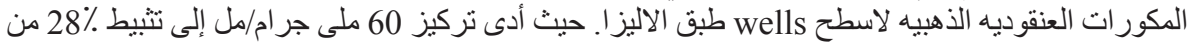

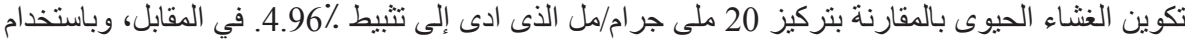

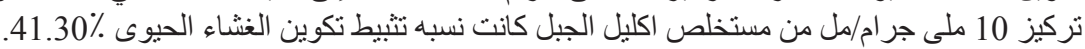

و علاوة على ذلك، تم تقييم الثأثير المثبط لكل من مستخلصات أوراق المورينجا أوليفير او اكليل الجبل بثكل

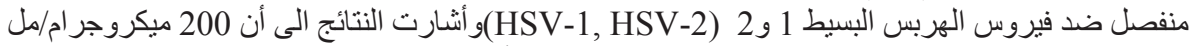

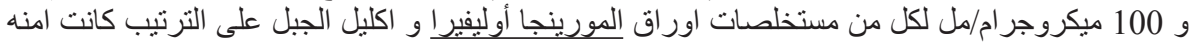

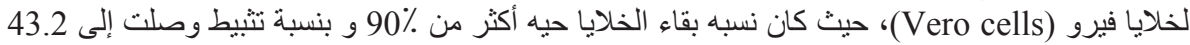

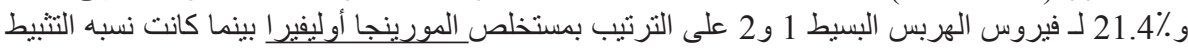

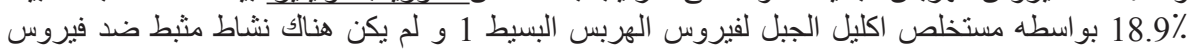

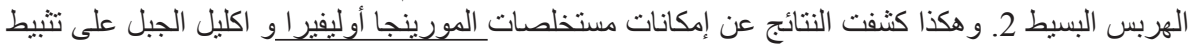

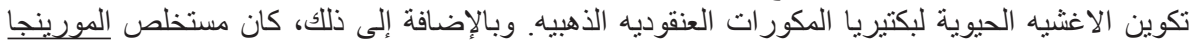

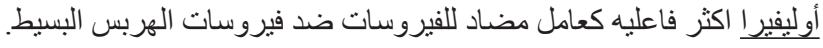

